\section{A Institucionalização das Pessoas com Deficiência no Brasil: Uma Análise sob a Ótica da Bioética}

\section{Bussinguer, Elda de Azevedo}

Faculdade de Direito de Vitória - FDV: Livre Docente pela UniRio; Doutora em Bioética pela UnB; Mestre em Direitos e Garantias Fundamentais pela FDV; Coordenadora do Programa de Pós-Graduação em Direitos e Garantias Fundamentais e de Pesquisa da FDV; Coordenadora do BIOGEPE - Grupo de Estudos, Pesquisa e Extensão em Políticas Públicas, Direito à Saúde e Bioética; Professora associada aposentada da UFES. Email: elda.cab@gmail.com

\section{Arantes, Maristela Lugon}

Mestre em Direitos e Garantias Fundamentais pela FDV Faculdade de Direito da Vitória; membro do BIOGEPE Grupo de Estudos, Pesquisa e Extensão em Políticas Públicas, Direito à saúde e Bioética; membro da Comissão de Direitos da Pessoa com Deficiência do Conselho Federal da $O A B$.

PALAVRAS-CHAVE: Pessoa com deficiência; Inclusão Social; Direito à Moradia; Bioética.

Introdução: Trata o presente artigo da análise, sob a ótica da bioética e dos direitos humanos, da situação de institucionalização em que ainda vivem milhares de pessoas com deficiência no Brasil. Dez anos após a ratificação da Convenção sobre o Direito das Pessoas com Deficiência (CDPD) da ONU e seu protocolo facultativo, pelo Estado Brasileiro e, dois anos de vigência da Lei Brasileira de Inclusão (Lei $\left.\mathrm{n}^{\circ} 13.146 / 15\right)$ que reconhecem a esse grupo o direito de viver incluído em sociedade, a institucionalização ainda é uma realidade no Brasil, segundo dados do relatório da Human Rights Watch, divulgado em maio de 2018. Com o tema "Eles ficam até morrer: uma vida de isolamento e negligência em instituições para pessoas com deficiência no Brasil. ", o relatório denuncia que no país existem 2.998 instituições de acolhimento para crianças, das quais 2.537 abrigam crianças com deficiência. A vida em instituições é limitadora dos direitos fundamentais dessas pessoas, condenando-as a viver segregadas. Programas estatais advindos com a política de desinstitucionalização são incapazes de incluir essas pessoas na sociedade, pois esbarram nas barreiras físicas e atitudinais impostas pela sociedade. Método: A metodologia utilizada para a elaboração deste artigo foi a pesquisa documental, sobretudo a análise do Relatório da Humans Rights Watch, e a bibliográfica. A partir dos pressupostos da bioética crítica, em especial a feminista, que rompe com a escola principialista norte americana, construída pelos países centrais, buscou-se trabalhar na perspectiva de uma bioética latino-americana, construída nos países periféricos, mais condizentes com a realidade brasileira, de enormes desigualdades sociais Resultado: A existência das pessoas com deficiência que vivem institucionalizadas é repleta de violências perpetradas pelo Estado, por meio das instituições que ainda refletem as políticas de abrigamento do século passado. Conclusões: A falta de políticas públicas que visem a inclusão e a real participação das pessoas com deficiência na comunidade tem como consequência a sua institucionalização e a violação de inúmeros direitos desse grupo. A bioética se apresenta como disciplina que pode embasar tais políticas públicas, buscando a efetiva implementação da CDPD no Brasil.

AGRADECIMENTOS: A minha família, inspiração maior; à amiga e conselheira professora Dra. Elda Bussinguer, à Dra. Izabel Maior, exemplo de luta e perseverança pelos Direitos da Pessoa com Deficiência e ao amigo Dr. Joelson Dias, pela atenção e oportunidades de atuação na militância.

\section{REFERÊNCIAS:}

[1] DINIZ, Débora. Modelo social da deficiência: a crítica feminista. RIUnb. Série Anis 28, Brasília, Letras Livres, 1-8, julho, 2003

[2] FOUCAULT, Michel. Os anormais. 3.ed. São Paulo: Martins Fontes. 2013.

[3] _. História da Loucura na Idade Clássica. 10.ed. São Paulo: Perspectiva. 2014.

[4] GARRAFA, Volnei; PORTO, Dora. Bioética, poder e injustiça: por uma ética de intervençäo. Mundo Saúde (Impr.), v. 26, n. 1, p. 6-15, 2002.

[5] GOFFMAN, Erving. Manicômios, prisões e conventos. São Paulo. Editora Perspectiva. 1974. 